\title{
Geometrical Model of Free Skin Graft for the Optimization of Glans Reconstruction after Partial Penectomy
}

\section{Modelo geométrico de injerto de piel libre para la optimización de reconstrucción de glande tras penectomía parcial}

\author{
Nicolas Fernandez ${ }^{1}$ Monica Medina ${ }^{2}$ Hunter Wessells ${ }^{1}$ Jaime Perez ${ }^{2}$
}

\author{
${ }^{1}$ Department of Urology, University of Washington. Seattle, \\ Washington, United States of America \\ 2 Division of Urology, Hospital Universitario San Ignacio, Pontificia \\ Universidad Javeriana, Bogota, Colombia
}

Address for correspondence Nicolas Fernandez, MD, PhD, Department of Urology, Seattle Children's Hospital, 4800 Sand Point Way, Seattle, WA 98105, United States (e-mail: nicolas.fernandez@seattlechildrens.org).

Urol Colomb 2021;30(3):e189-e193.

\begin{abstract}
Introduction and Objective The management of penile carcinoma is very disabling and mutilating, bur early treatment can be curative. Our group systematically performs oncological management with immediate penile reconstruction and preservation of the organ (partial penectomy, resurfacing, or glansectomy) when feasible. Due to the low incidence of penile carcinoma, it is difficult to achieve experience in penile reconstruction using free grafts in a standardized and reproducible way. Therefore, we herein present the results of the use of an inanimate model to identify the most efficient geometric way to procure and apply a free skin graft to reconstruct the penis. Methods A preclinical inanimate model of the penis was developed to simulate the surgical reconstruction using a free skin graft. Six different geometric skin-graft models were created and tested. For each of them, we measured graft's surface area as well as the discarded surface after placing the graft on the penis for reconstruction. We also measured the amount of suture lines required for reconstruction. All of these measurements in the six different models were compared.

Results Based on the six models, we identified that the longitude of the graft must measure the same as the maximum perimeter of the glans in order to have a square that enables the complete coverage of the penile defect. The total graft area for the first 4 models was of $40 \mathrm{~cm}^{2}$; for models 5 and 6 , it was of $60 \mathrm{~cm}^{2}$. The average discarded area of

Keywords

- penile cancer

- resurfacing

- skin graft the graft was of $18.135 \mathrm{~cm}^{2}$ (range: $12 \mathrm{~cm}^{2}$ to $30 \mathrm{~cm}^{2}$ ). Models 4 years 6 were the ones with the least discarded tissue: $12 \mathrm{~cm}^{2}$. The average amount of suture lines to secure the different model grafts was 7.3 (range: 5 to 12). The models that required the least amount of suture lines were number 1 and 4 , with a total of 5 suture lines.
\end{abstract}

received

January 2, 2021

accepted

March 31, 2021

published online

August 23, 2021
DOI https://doi.org/

$10.1055 / \mathrm{s}-0041-1731771$

ISSN 0120-789X.

e ISSN 2027-0119.
(C) 2021. Sociedad Colombiana de Urología. All rights reserved. This is an open access article published by Thieme under the terms of the Creative Commons Attribution-NonDerivative-NonCommercial-License, permitting copying and reproduction so long as the original work is given appropriate credit. Contents may not be used for commercial purposes, or adapted, remixed, transformed or built upon. (https://creativecommons.org/ licenses/by-nc-nd/4.0/)

Thieme Revinter Publicações Ltda., Rua do Matoso 170, Rio de Janeiro, RJ, CEP 20270-135, Brazil 


\section{Resumen}

Palabras Clave

- cáncer de pene

- desepitelización

- injerto de piel
Conclusions The double trapezoid is the most efficient model to reconstruct the glans after organ-sparing oncological management. Our results contribute to establish a more standardized and predictable technique to reconstruct the penis.

Introducción y Objetivo El manejo del cáncer de pene es muy mutilante y discapacitante. Pero el manejo quirúrgico oportuno puede ser curativo. Nuestro grupo realiza de manera sistemática el manejo oncológico con reconstrucción inmediata del pene y preservación del órgano (penectomía parcial, desepitelización, o gladectomía) cuando sea viable. Como la incidencia de cancer de pene es baja, lograr obtener la experiencia en reconstrucción de pene con el uso de injertos libres de manera estandarizada y reproducible resulta difícil. Por lo tanto, presentamos en este artículo los resultados de un modelo inanimado para identificar la forma geométrica mas eficiente de obtener y aplicar un injerto de piel libre para reconstruir el pene.

Materiales y Métodos Se desarrolló un modelo preclínico y inanimado del pene para que se simulara su reconstrucción quirúrgica con el uso de un ijerto de piel libre. Desarrollamos y evaluamos seis modelos geométricos de injerto de piel distintos. Para cada uno, medimos el area total del injerto y la del tejido desechado tras ponerlo en el pene para la recosntrucción. También medimos la cantidad de líneas de sutura necesarias para la recosntrucción. Comparamos todas las medidas entre los seis modelos distintos.

Resultados De los 6 modelos diferentes, encontramos que la longitud del injerto debe tener la misma medida que el perímetro máximo del glande para que se tenga un cuadrado que nos permita cubrir todo el defecto del pene. El area total de los 4 modelos iniciales fue de $40 \mathrm{~cm}^{2}$, y el area de los modelos 5 y 6 fue de $60 \mathrm{~cm}^{2}$. El area promedio del tejido desechado en los injertos fue de $18,135 \mathrm{~cm}^{2}$ (rango: $12 \mathrm{~cm}^{2}$ a $30 \mathrm{~cm}^{2}$ ). Los modelos 4 y 6 fueron los que tuvieron la menor cantidad de tejido desechado: $12 \mathrm{~cm}^{2}$. El promedio de la cantidad de líneas de sutura para atar los distintos modelos de injerto fue de 7,3 (rango: 5 a 12). Los modelos con la menor cantidad de líneas de sutura fueron el 1 y el 4 , con un total de 5 líneas.

Conclusiones El modelo de doble trapezoide es el más eficiente para reconstruir el glande tras el majejo oncológico en que se preserva el órgano. Nuestros resultados contribuyen para establecer una técnica de reconstrucción del pene más estandarizada y previsible.

\section{Introduction}

Penile cancer affects around $1 \%$ of men in developed countries. About $10 \%$ of these tumors present as carcinoma in-situ (CIS), and are prone to conservative management. ${ }^{1}$ The most common presenting location for malignant penile cancer is the glans and/or prepuce, with $\sim 78 \%$ of the lesions detected at this location. ${ }^{2}$ Glans resurfacing is one of the few techniques used to treat non-invasive penile cancer that is confined to the glans. Currently, the European Association of Urology guidelines recommend conservative surgery as a primary option for the management of superficial non-invasive disease (penile intraepithelial neoplasia, PeIN), or as a secondary option after failure of topical chemotherapy or laser therapy. ${ }^{3}$ It is also recommended as a primary option for the management of Ta, T1a (G1, G2) tumors. ${ }^{4}$ The technique for glans resurfacing total (total glans resurfacing,
TGR) or partial (partial glans resurfacing, PGR: excision of less than $50 \%$ of the glans epithelium). ${ }^{4,5}$ Partial resurfacing is usually indicated in cases of localized CIS affecting less than $50 \%$ of the glans. ${ }^{4}$ The goal of reconstruction is to restore the cosmesis and function of the organ. ${ }^{6,7}$ This entails retaining or restoring the ability to urinate while standing, to achieve erection and sexual penetration, and to maintain erogenous sensation. ${ }^{2}$ The overall satisfaction rate and recovery of the sexual function are acceptable, and it could be considered an ideal treatment. ${ }^{4}$

Considering the feasibility of performing oncological and reconstructive management simultaneously, surgeons treating these conditions need to achieve and master both techniques. Given the low frequency of this condition, the case volume is a limiting factor to have a significant case $\log$ to become proficient in this technique. Furthermore, the limited reproducibility and standardization to effectively 
procure and use the graft makes this surgery more challenging. Therefore, the aim of the present manuscript is to describe the results of an inanimate model to identify an efficient and standard way to procure, prepare and secure the skin graft.

\section{Methods}

A preclinical experiment using an inanimate penile model was used to simulate a glans resurfacing scenario. The penile dummy was made from silicone and had a circumference at the glans of $10 \mathrm{~cm}$ in its widest point, and a total longitude of $14 \mathrm{~cm}$. The skin graft was simulated using a moist disposable polyester towel (with a thickness of $0.045 \mathrm{~cm}$ ) considering its physical similarities to a partial thickness skin graft. ${ }^{8}$ The dimensions of the skingraft model were initially based on our clinical experience of procurement of rectangular skin grafts considering the technical limitation of the shape of the dermatome. The first adjustment was to use a rectangular length that would secure a complete circumferential coverage of the glans. The width of the graft was based on the measurement of the distance between the tip of the glans and the coronal sulcus. For each model, we arbitrarily designed 6 different geometrical shapes (-Table 1). For each shape, a resurfacing procedure was simulated. All models were designed to achieve 100\% coverage of the glans defect. The shape of each model is presented in -Table $\mathbf{1}$.

Total surface area, required sutures lines to secure the graft to glans and the discarded graft area was measured for each model define the best and most efficient model.

We developed six geometric models, as follows:

Model 1: Simple crown. To obtain the width of the skingraft model, we measured the distance between the urethral meatus and the edge of the coronal sulcus. The circumference of the glans at its widest point translated into the length of the model. The graft was prepared as a rectangular shape; it was placed around the coronal sulcus, resulting in a cylinder figure. The dorsal end of the graft was then brought closer to the urethral meatus fixing it to the

Table 1 Model shapes and description of area of coverage

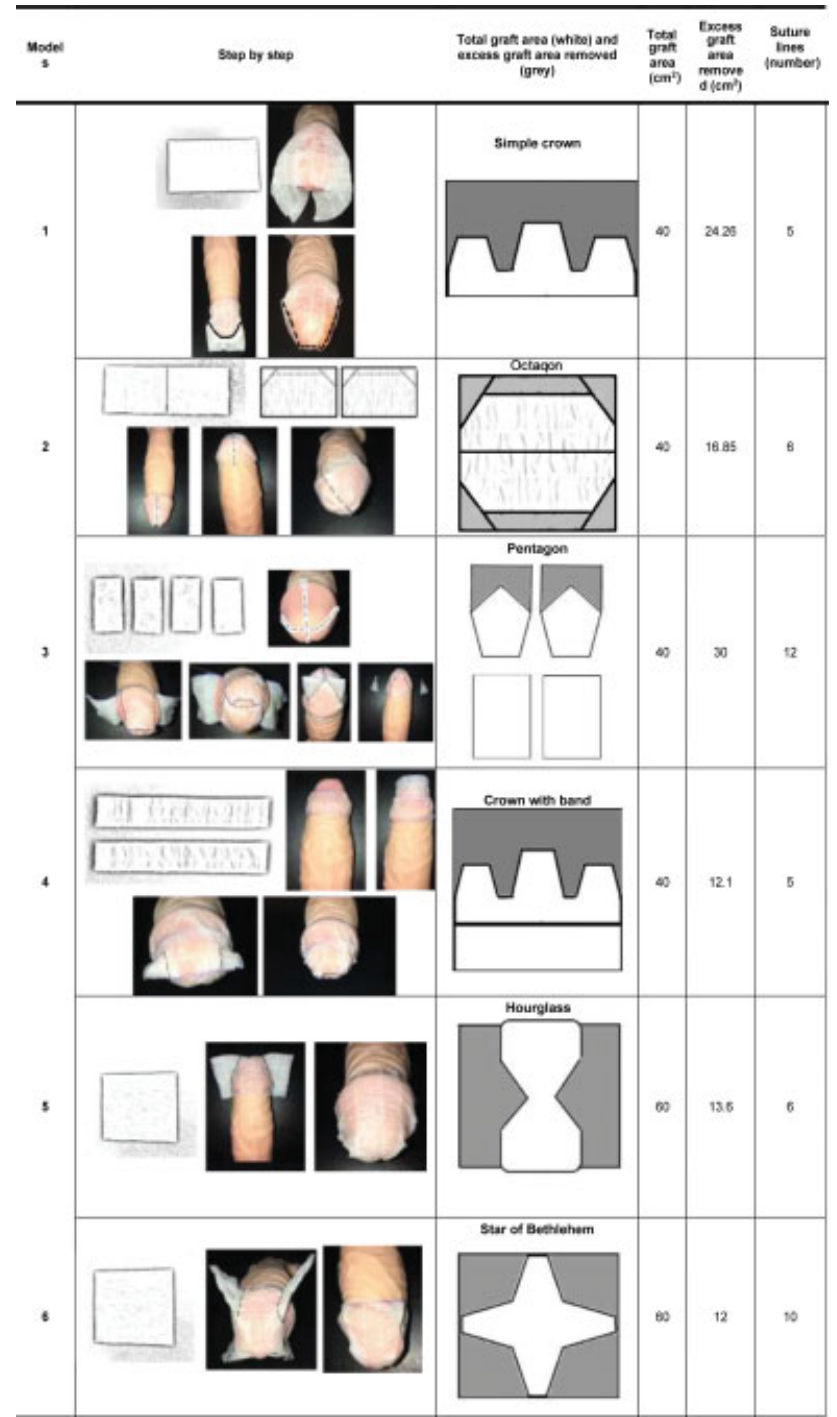


surface. The excess area was removed with scissors, achieving $100 \%$ of surface coverage ( - Table 1 ).

Model 2: Octagon. Same measurements and shapes were used as in model 1 . The rectangle was divided in half to obtain two non-equilateral squares. Each graft square was altered to a half-moon shape with a rectangular base. To provide a curvature to the upper part of the graft, a triangle was drawn in each corner. The triangles and the area over the dotted line were removed with scissors, covering $100 \%$ of the right half of the glans. The same procedure was performed on the left side of the glans (-Table 1).

Model 3: Pentagon. The size and shape of the graft were the same as in model 1 . The rectangle was divided perpendicularly to its length in four equal parts, obtaining four separate squares. The glans was divided into four quadrants (dorsal, ventral, right side and left side). Each square was first fixed at the dorsal and ventral quadrants, then the lateral ones were secured removing the overlapped tissue ( - Table 1 ).

Model 4: Crown with band. The measurements were the same as those used in model 1 . The graft was divided longitudinally in two equal parts. The glans was divided horizontally into a proximal and a distal portion, and the graft was first fixed to the most proximal part and then to the most distal part around the urethral meatus. The excess tissue was trimmed (-Table $\mathbf{1}$ ).

Model 5: Hourglass. The distance between the urethral meatus and the coronal sulcus of the glans on the left and right sides was used to get the length of the graft. The rectangular graft was placed perpendicularly above the glans, covering it as an "umbrella." The edges were stitched to the edge of the coronal skin (-Table 1 ).

\section{Results}

In the comparison of the six geometrical shapes, we identified that model 4 (crown with band) had the shape with the least discarded surface and the least amount of suture lines (-Table 1). Models 1, 2, 3 and 4 had a total graft area of $40 \mathrm{~cm}^{2}$. Regarding the total area of the discarded graft, model 1 had $24.26 \mathrm{~cm}^{2}$, and used 5 suture lines; model 2, it was of $16.85 \mathrm{~cm}^{2}$, with 6 suture lines; for model 3, $30 \mathrm{~cm}^{2}$, with 12 suture lines; and, for model $4,12.1 \mathrm{~cm}^{2}$ and 5 suture lines. Models 5 and 6 had a total graft area of $60 \mathrm{~cm}^{2}$. Model 5 had a removed excess area of $13.6 \mathrm{~cm}^{2}$, with 6 suture lines, And model $6,12 \mathrm{~cm}^{2}$, with 10 suture lines.

\section{Discussion}

Immediate reconstruction after surgical management has proven to be safe and feasible. Surgeons need to consider this simultaneous treatment as a standard of care. ${ }^{9}$ Since reconstructive surgery requires special surgical principles and skills, the success of the graft placement may depend on the surgeon's experience. Our results contribute to facilitate training and standardize the reconstructive technique. To our knowledge, this is the first time such an approach is reported and applied to identify the most efficient geometrical model to perform immediate penile glans resurfacing. Given the low prevalence of penile carcinoma, we believe that our novel results, using the technique presented in model 4, will help surgeons in the preparation and placement of the graft. Although probably not clinically significant, models1 to 4 had smaller total graft areas, which may result in a smaller scar on the donating area. We acknowledge that grafts do retract $\sim 10 \%$ to $20 \%$ once healed. ${ }^{10}$ When our results are translated into the clinical scenario, it may be important that surgeons applying this technique keep this fact in mind.

Furthermore, models 4 and 6 had the lowest amount of discarded excess area. of $\sim 12 \mathrm{~cm}^{2}$ in comparison to the other models. Nonetheless, measuring the discarded tissue areas, it is interesting to notice that discarded tissue may be as high as $75 \%$ of the graft's total area. This may have more clinical relevance when larger surface areas need to be reconstructed.

Based on our clinical experience in this field, we do not believe that suture lines clearly manifest as a visible scar affecting the clinical esthetic results. ${ }^{11}$ Nonetheless, we included the amount of suture lines in our analysis considering the probability that the fewer the sutures, the shorter the operative time; and it may reduce complications such as hematomas and graft loss due to poor take along the suture lines. Further clinical studies are needed.

A limitation of the present article is the lack of clinical data. Nonetheless, to overcome this, we started with an inanimate penile model to test our concept; it could also be used as a possible training model for residents, considering the low prevalence of the condition.

\section{Conclusion}

Our results may contribute to the standardizationof a surgical technique for glans resurfacing and to facilitate graft harvesting for better reproducibility and training. Future studies may include the evaluation and impact of our model on resident's training as well as clinical results.

Conflict of Interests

The authors have no conflict of interests to declare.

\section{References}

1 Pérez-Niño J, Fernandez N, Sarmiento G. Partial penectomy and penile reconstruction. Initial surgical management of localized penile cancer. Actas Urol Esp 2014;38(01):62-65

2 Bickell M, Beilan J, Wallen J, Wiegand L, Carrion R. Advances in Surgical Reconstructive Techniques in the Management of Penile, Urethral, and Scrotal Cancer. Urol Clin North Am 2016;43(04): 545-559

3 Bada $\mathrm{M}$, Berardinelli $\mathrm{F}$, Nyiràdy $\mathrm{P}$, et al. Adherence to the EAU guidelines on Penile Cancer Treatment: European, multicentre, retrospective study. J Cancer Res Clin Oncol 2019;145(04):921-926http://www.ncbi.nlm.nih.gov/pubmed/30825028 cited 2019Dec9 [Internet] 
4 Pappas A, Katafigiotis I, Waterloos M, Spinoit AF, Ploumidis A. Glans Resurfacing with Skin Graft for Penile Cancer: A Step-byStep Video Presentation of the Technique and Review of the Literature. BioMed Res Int 2019;2019:5219048

5 Kamel MH, Bissada N, Warford R, Farias J, Davis R. Organ Sparing Surgery for Penile Cancer: A Systematic Review. J Urol 2017;198 (04):770-779

6 Corbishley CM, Tinwell B, Kaul A, Ayres B, Watkin NA. Glans resurfacing for precancerous and superficially invasive carcinomas of the glans penis: Pathological specimen handling and reporting. Semin Diagn Pathol 2015;32(03):232-237

7 Pietrzak P, Corbishley C, Watkin N. Organ-sparing surgery for invasive penile cancer: early follow-up data. BJU Int 2004;94(09): 1253-1257
8 Brown JE, Holloway SL. An evidence-based review of split-thickness skin graft donor site dressings. Int Wound J 2018;15(06): 1000-1009http://www.ncbi.nlm.nih.gov/pubmed/30117716 cited 2020Mar21 [Internet]

9 Gómez-Ferrer Á, Rubio-Briones J, Collado A, et al. Reconstrucción del glande con injerto cutáneo libre según técnica de Bracka. Actas Urol Esp 2011;35(03):180-183

10 Rincón LF, Ramos G, Patiño G. Reconstrucción genitourinaria en paciente con quemadura eléctrica y compromiso pélvico secundario a efecto de polo de salida. Urol Colomb. 2016;25(03): 270-273

11 Pérez J, Chavarriaga J, Ortiz A, et al. Oncological and Functional Outcomes After Organ-Sparing Plastic Reconstructive Surgery for Penile Cancer. Urology 2020;142(01):161-165.e1 